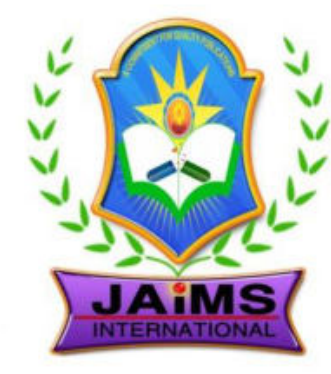

ISSN 2456-3110

Vol $5 \cdot$ Issue 1

Jan-Feb 2020

Journal of

Ayurveda and Integrated Medical Sciences

www.jaims.in

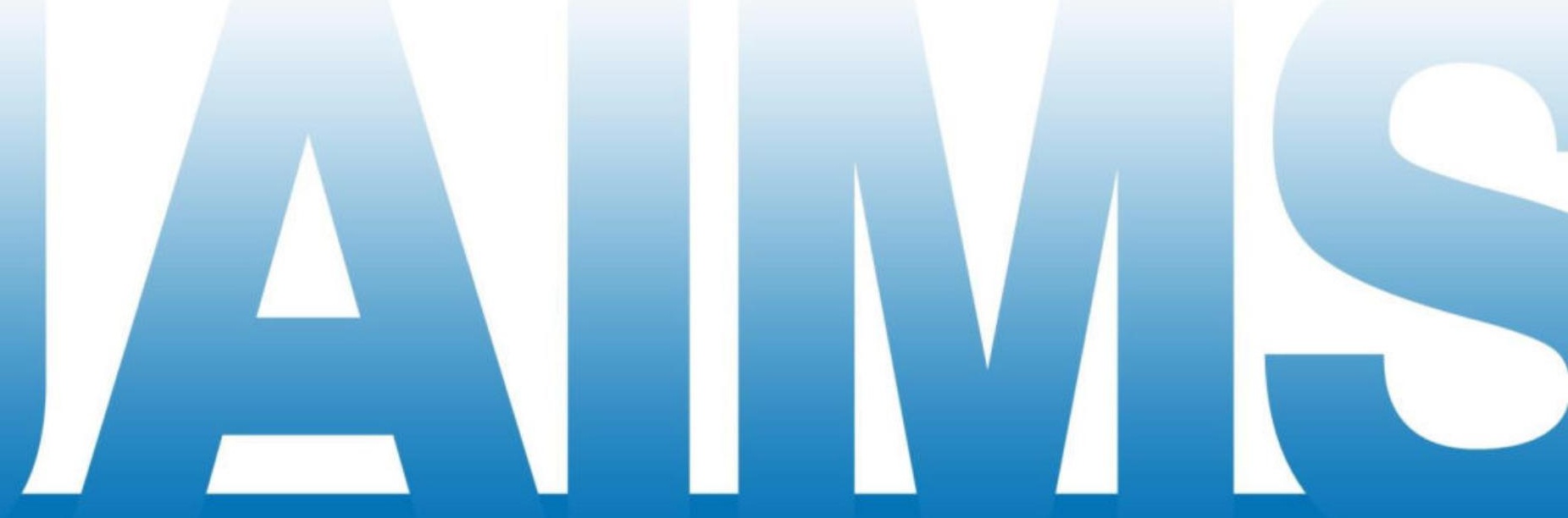

An International Journal for Researches in Ayurveda and Allied Sciences

\title{
Charaka
}




\title{
Ayurveda and Integrated Medical Sciences
}

\section{Evaluation of the efficacy of Shiva modaka on Hematological, Biochemical and Immunological Parameters in the management of malnutrition among school going children}

Dr. Pradeep EK ${ }^{1}$, Dr. Ravishankar Shenoy ${ }^{2}$

${ }^{1}$ Assistant Professor, ${ }^{2}$ Professor, Muniyal Institute of Ayurveda Medical Sciences, Manipal, Karnataka, INDIA.

\section{A B S TRACT}

\begin{abstract}
Malnutrition is an issue of global dimensions affecting all ages. Malnutrition in children is common in early age especially during infancy and weaning. However, it also prevails during early schooling. In adults and elderly it is studied as under Protein Energy Malnutrition. It has not only short term adverse effects but also exhibits long term sustained and progressive effects. Kuposhana/Bala Shosha is explained in the Ayurveda literatures and elaborate therapeutic interventions are also described. The disease Karshya also applies to this condition. Shiva Modaka, a drug described under Bala Roga seems to act on vide dimensions of pediatric health with indications in common pediatric ailments too. The present clinical study is an effort to evaluate the efficacy of the said drug on hematological, biochemical and immunological parameters in Malnutrition in school going children.
\end{abstract}

Key words: Malnutrition, Bala Shosha, Kuposhana, Shiva Modaka, Karshya, Hematological, Biochemical, Immunological.

\section{INTRODUCTION}

Malnutrition is a mirror to the social status in which the people are living. It is a big challenge to the country. Malnutrition in growing children poses a major problem to the physical and mental development. ${ }^{[1,2]}$ Protein Energy Malnutrition is also considered in the purview. ${ }^{[4]}$ Kuposhana/Bala Shosha is explained long back and many remedial measures have been explained for the same in Ayurveda treatise. ${ }^{[6-10]}$ Failure to thrive and susceptibility to other diseases are the main implications. ${ }^{[3,5]}$ Shiva Modaka explained in Bhaishajya Ratnavali, Bala Roga

\section{Address for correspondence:}

\section{Dr. Pradeep EK}

Assistant Professor, Muniyal Institute of Ayurveda Medical

Sciences, Manipal, Karnataka, INDIA.

E-mail: edakkana@gmail.com

Submission Date: 07/01/2020 Accepted Date: 19/02/2020

Quick Response Code

Adhikara is selected for the present study. ${ }^{[11]}$ Hence, present study has been carried out to bring out the best possible key to solve the malnutrition problem.

\section{Materials And Methods}

The ingredients of Shiva modaka were procured from genuine sources and the preparation was done at Dr. Krisna Muniyal life sciences Pvt Ltd, Manipal.

Dosage

$5 \mathrm{~g}$ single dose, empty stomach in the morning with milk.

\section{Duration of the study}

3 months, during which BMI, anthropometric measurements, IQ level and subjective assessments were done on monthly basis. Hematological, Biochemical and Immunological investigations were done before and after the intervention.

Source of data

Patients fulfilling the diagnostic criteria of malnutrition were selected from government schools of Udupi district. A total of 60 students fulfilling the 
diagnostic criteria were selected for the study in a single group.

\section{Inclusion Criteria}

The children between ages 5-10 years suffering from malnutrition were included in the present study on the basis of IAP criteria for diagnosis of PEM - Grade I: Patients with $71-80 \%$ of expected weight for age, Grade II: Patients with 61 - 70\% of expected weight for age, Grade III: Patients with $51-60 \%$ of expected weight for age, Grade IV: Patients with $<50 \%$ of expected weight for age [1]

\section{Exclusion Criteria}

Cases with devitalizing diseases like Tuberculosis, Malabsorption syndrome, Chronic diarrhoea, congenital heart disease, Mental retardation, Cerebral palsy, Mongolism, seizure and any sort of grave diseases.

\section{Investigations}

Haemoglobin percentage, lipid profile, serum protein, Immunoglobulin assay (Ig $M$ and Ig A) were investigated before and after treatment.

\section{Criteria for assessment of patients}

The clinical evaluation of the patient was done by following particulars.

Objective assessment - The objective assessment was done on the basis of the Investigation report of the patient, IQ level, BMI and the anthropometric measurements before and after the treatment.

Subjective assessment - The subjective assessment was made on the basis of signs and symptoms and divided in three groups as + Mild degree of sign and symptoms, ++ Moderate degree of sign and symptoms, +++ Severe degree of sign and symptoms.

\section{Clinical Assessment of Result}

The values of Hematological, Biochemical and Immunological tests before and after treatment were compared. The symptom scores were also assessed before and after treatment.

\section{RESULT}

The Data collected from the study are grouped as under
Number of Subjects: 60

Mean Age of Subjects: 8.37 (yrs)

\begin{tabular}{|c|c|c|c|c|c|c|c|c|c|c|c|}
\hline \multicolumn{2}{|c|}{$\begin{array}{l}\text { Param } \\
\text { eter }\end{array}$} & $\mathrm{Hb}$ & $\begin{array}{l}\text { T.C } \\
\text { ho }\end{array}$ & $\begin{array}{l}\text { HD } \\
L\end{array}$ & $\begin{array}{l}\text { T. } \\
\text { Pr }\end{array}$ & IQ & $\begin{array}{l}\text { B } \\
\text { MI }\end{array}$ & $\begin{array}{l}\mathrm{He} \\
\text { igh }\end{array}$ & $\begin{array}{l}\text { W } \\
\text { eig }\end{array}$ & $\begin{array}{l}\mathrm{H} \\
\text { ea }\end{array}$ & $\begin{array}{l}\text { Ch } \\
\text { es }\end{array}$ \\
\hline \multirow{6}{*}{$\begin{array}{l}\text { M } \\
\text { ea } \\
n\end{array}$} & $B$ & 11. & 15 & 53. & 7. & 86 & 13. & 12 & 19. & 50 & 61 \\
\hline & $\mathrm{T}$ & 31 & 6.4 & 75 & 38 & .4 & 11 & 1.9 & 41 & .4 & .9 \\
\hline & & 6 & 0 & 7 & 7 & 0 & 6 & 9 & & 0 & 0 \\
\hline & A & 12. & 15 & 49. & 7. & 87 & 15. & 12 & 22. & 50 & 62 \\
\hline & $T$ & 04 & 1.1 & 52 & 16 & .0 & 03 & 3.2 & 38 & .6 & .3 \\
\hline & & 7 & 2 & 3 & 3 & 0 & 2 & 1 & & 8 & 0 \\
\hline
\end{tabular}

Mean of the values of various parameters are showed in the table which shows improvement in Hemoglobin percent, IQ, BMI, Height, Weight, Head circumference and Chest circumference. Total Protein, Lipid Profiles showed mixed results. Immunological tests such as $\operatorname{IgM}$ and IgA values showed lot of variation in the subjects before treatment. However after treatment the variation reduced.

\section{Discussion}

Analysis of Data obtained by the clinical study shows that the individual data showed an Extreme Variation (Outline Values) in certain parameters such as Triglycerides, LDL cholesterol, VLDL Cholesterol, IgM and IgA. Though the intended Statistical tool initially suggested was Students' Paired " $T$ " Test, in case of Outline Values the calculated Mean is not all suitable. Hence, Wilcoxon's Signed Rank Test was used for the above 5 parameters. The other parameters were analysed based on Paired " $\mathrm{T}$ " test.

\begin{tabular}{|c|c|c|c|c|c|c|c|c|c|c|c|}
\hline \multirow{2}{*}{$\begin{array}{l}\text { Par } \\
\text { am } \\
\text { eter }\end{array}$} & \multicolumn{3}{|c|}{ Mean } & \multirow[t]{2}{*}{$\mathbf{N}$} & \multicolumn{3}{|l|}{ S.D. } & \multicolumn{2}{|l|}{ S.E. } & \multicolumn{2}{|c|}{$P$ value } \\
\hline & BT & AT & Dif & & BT & AT & Dif & BT & AT & & \\
\hline $\mathrm{Hb}$ & $\begin{array}{l}11 . \\
31 \\
62\end{array}$ & $\begin{array}{l}12 . \\
04 \\
70\end{array}$ & $\begin{array}{l}- \\
.73 \\
08\end{array}$ & $\begin{array}{l}6 \\
0\end{array}$ & $\begin{array}{l}1.5 \\
09 \\
26\end{array}$ & $\begin{array}{l}1.2 \\
30 \\
11\end{array}$ & $\begin{array}{l}1.7 \\
13 \\
91\end{array}$ & $\begin{array}{l}.1 \\
94 \\
84\end{array}$ & $\begin{array}{l}.1 \\
58 \\
81\end{array}$ & $\begin{array}{l}0 . \\
0 \\
7 \\
7\end{array}$ & $\begin{array}{l}> \\
0 . \\
0 \\
5\end{array}$ \\
\hline T.C & $\begin{array}{l}15 \\
6.4\end{array}$ & $\begin{array}{l}15 \\
1.1\end{array}$ & 5.2 & 6 & $\begin{array}{l}22 . \\
92\end{array}$ & $\begin{array}{l}30 . \\
78\end{array}$ & $\begin{array}{l}32 . \\
49\end{array}$ & $\begin{array}{l}2 . \\
96\end{array}$ & $\begin{array}{l}3 . \\
97\end{array}$ & $\begin{array}{l}0 . \\
0\end{array}$ & $\begin{array}{l}< \\
0 .\end{array}$ \\
\hline
\end{tabular}




\begin{tabular}{|c|c|c|c|c|c|c|c|c|c|c|c|}
\hline hol & 0 & 2 & 83 & 0 & 4 & 5 & 5 & 0 & 4 & $\begin{array}{l}2 \\
2\end{array}$ & $\begin{array}{l}0 \\
5\end{array}$ \\
\hline $\begin{array}{l}\mathrm{HD} \\
\mathrm{L}\end{array}$ & $\begin{array}{l}53 . \\
75 \\
7\end{array}$ & $\begin{array}{l}49 . \\
52 \\
3\end{array}$ & $\begin{array}{l}4.2 \\
33\end{array}$ & 6 & $\begin{array}{l}9.6 \\
92 \\
9\end{array}$ & $\begin{array}{l}9.9 \\
51 \\
3\end{array}$ & $\begin{array}{l}10 . \\
76 \\
61\end{array}$ & $\begin{array}{l}1 . \\
25 \\
14\end{array}$ & $\begin{array}{l}1 . \\
28 \\
47\end{array}$ & $\begin{array}{l}0 . \\
0 \\
0 \\
2\end{array}$ & $\begin{array}{l}< \\
0 . \\
0 \\
5\end{array}$ \\
\hline $\begin{array}{l}\text { Tot } \\
\text { al } \\
\text { Pro } \\
\text { tei } \\
\text { n }\end{array}$ & $\begin{array}{l}7.3 \\
87\end{array}$ & $\begin{array}{l}7.1 \\
63\end{array}$ & $\begin{array}{l}.22 \\
3\end{array}$ & 6 & $\begin{array}{l}.74 \\
59\end{array}$ & $\begin{array}{l}1.0 \\
62 \\
5\end{array}$ & $\begin{array}{l}.98 \\
38\end{array}$ & $\begin{array}{l}.0 \\
96 \\
3\end{array}$ & $\begin{array}{l}.1 \\
37 \\
2\end{array}$ & $\begin{array}{l}0 . \\
0 \\
0 \\
0\end{array}$ & $\begin{array}{l}< \\
0 . \\
0 \\
5\end{array}$ \\
\hline IQ & $\begin{array}{l}86 . \\
40\end{array}$ & $\begin{array}{l}87 . \\
00\end{array}$ & $\begin{array}{l}- \\
.60 \\
0\end{array}$ & 6 & $\begin{array}{l}4.8 \\
82\end{array}$ & $\begin{array}{l}4.4 \\
87\end{array}$ & $\begin{array}{l}1.1 \\
82\end{array}$ & $\begin{array}{l}.6 \\
30\end{array}$ & $\begin{array}{l}.5 \\
79\end{array}$ & $\begin{array}{l}0 . \\
0 \\
0 \\
0\end{array}$ & $\begin{array}{l}< \\
0 . \\
0 \\
5\end{array}$ \\
\hline $\begin{array}{l}\text { BM } \\
\text { I }\end{array}$ & $\begin{array}{l}13 . \\
11 \\
68\end{array}$ & $\begin{array}{l}15 . \\
03 \\
20\end{array}$ & $\begin{array}{l}- \\
1.9 \\
15 \\
17\end{array}$ & 6 & $\begin{array}{l}1.9 \\
72 \\
23\end{array}$ & $\begin{array}{l}1.9 \\
70 \\
93\end{array}$ & $\begin{array}{l}1.5 \\
65 \\
37\end{array}$ & $\begin{array}{l}.2 \\
54 \\
61\end{array}$ & $\begin{array}{l}.2 \\
54 \\
45\end{array}$ & $\begin{array}{l}0 . \\
0 \\
0 \\
0\end{array}$ & $\begin{array}{l}< \\
0 . \\
0 \\
5\end{array}$ \\
\hline $\begin{array}{l}\text { Hei } \\
\text { ght }\end{array}$ & $\begin{array}{l}12 \\
1.9 \\
92\end{array}$ & $\begin{array}{l}12 \\
3.2 \\
17\end{array}$ & $\begin{array}{l}- \\
1.2 \\
25 \\
0\end{array}$ & 0 & $\begin{array}{l}9.5 \\
12 \\
0\end{array}$ & $\begin{array}{l}9.4 \\
98 \\
6\end{array}$ & $\begin{array}{l}.54 \\
01\end{array}$ & $\begin{array}{l}1 . \\
22 \\
80\end{array}$ & $\begin{array}{l}1 . \\
22 \\
63\end{array}$ & $\begin{array}{l}0 . \\
0 \\
0 \\
0\end{array}$ & $\begin{array}{l}0 . \\
0 \\
5\end{array}$ \\
\hline $\begin{array}{l}\text { We } \\
\text { ight }\end{array}$ & $\begin{array}{l}19 . \\
41 \\
8\end{array}$ & $\begin{array}{l}22 . \\
38 \\
3\end{array}$ & $\begin{array}{l}- \\
2.9 \\
65 \\
0\end{array}$ & $\begin{array}{l}6 \\
0\end{array}$ & $\begin{array}{l}4.3 \\
96 \\
5\end{array}$ & $\begin{array}{l}4.3 \\
53 \\
4\end{array}$ & $\begin{array}{l}1.6 \\
90 \\
6\end{array}$ & $\begin{array}{l}.5 \\
67 \\
6\end{array}$ & $\begin{array}{l}.5 \\
62 \\
0\end{array}$ & $\begin{array}{l}0 . \\
0 \\
0 \\
0\end{array}$ & $\begin{array}{l}0 \\
0\end{array}$ \\
\hline $\begin{array}{l}\mathrm{He} \\
\text { ad } \\
\text { Circ } \\
\text { um }\end{array}$ & $\begin{array}{l}50 . \\
40\end{array}$ & $\begin{array}{l}50 . \\
68 \\
3\end{array}$ & $\begin{array}{l}- \\
.28 \\
33\end{array}$ & 0 & $\begin{array}{l}.97 \\
8\end{array}$ & $\begin{array}{l}.93 \\
41\end{array}$ & $\begin{array}{l}.38 \\
36\end{array}$ & $\begin{array}{l}.1 \\
26\end{array}$ & $\begin{array}{l}.1 \\
20 \\
6\end{array}$ & $\begin{array}{l}0 . \\
0 \\
0 \\
0\end{array}$ & $\begin{array}{l}0 \\
5\end{array}$ \\
\hline $\begin{array}{l}\text { Che } \\
\text { st } \\
\text { Circ } \\
\text { um }\end{array}$ & $\begin{array}{l}61 . \\
90 \\
8\end{array}$ & $\begin{array}{l}62 . \\
30 \\
0\end{array}$ & $\begin{array}{l}- \\
.39 \\
17\end{array}$ & 6 & $\begin{array}{l}1.9 \\
27 \\
7\end{array}$ & $\begin{array}{l}1.6 \\
87 \\
9\end{array}$ & $\begin{array}{l}.42 \\
28\end{array}$ & $\begin{array}{l}.2 \\
48 \\
9\end{array}$ & $\begin{array}{l}.2 \\
17 \\
9\end{array}$ & $\begin{array}{l}0 . \\
0 \\
0 \\
0\end{array}$ & $\begin{array}{l}0 \\
5\end{array}$ \\
\hline
\end{tabular}

Hemoglobin though showed some improvement after treatment, the Mean value Before treatment being 11.3162 and AT the Mean $\mathrm{Hb}$ being 12.0470 it was not statistically significant $(\mathrm{P}>0.05)$.

Total Cholesterol showed a borderline decrease in Mean values from 156.4 before treatment to 151.12 after treatment which was statistically significant $(\mathrm{P}<0.05)$.
Total Protein showed a slight reduction from mean value of 7.387 BT to 7.163 which was statistically significant $(P<0.05)$.

IQ level showed a borderline increase from Mean 86.4 BT to 87 AT and the improvement was statistically significant $(P<0.05)$.

Mean value of Body Mass Index (BMI) before treatment was 13.1168 which increased to 15.0320 and the improvement was statistically significant $(P<0.05)$.

The Mean Height before treatment was $121.992 \mathrm{~cm}$ which increased to $123.217 \mathrm{~cm}$ and was statistically significant $(P<0.05)$

The change in Weight from Mean Value of 19.418 before treatment to 22.383 after treatment was statistically significant $(P<0.05)$.

Head circumference changed from the mean value of 50.4 before treatment to 50.683 after treatment which was statistically significant $(P<0.05)$.

The Chest circumference improved slightly from a mean value 61.908 before treatment to 62.300 after treatment which was statistically significant $(P<0.05)$.

The parameters such as Triglyceride, LDL, VLDL, IgM and IgA with Extreme (Outline) Values were subjected to Wilcoxon's Signed Rank Test and 2-tailed test which showed that the results were significant and the variability of the values in these parameters reduced significantly after treatment.

Overall assessment of improvement in IAP scale and Symptoms suggested $80.5 \%$ of the subjects obtained significant relief of symptoms with treatment and about $19.5 \%$ obtained moderate relief.

\section{CONCLUSION}

The study concludes that the drug Shiva Modaka is very beneficial in the management of Malnutrition in the school going children of age 5-10 years. It significantly relieved the symptoms of Malnutrition and other associated symptoms and also helped to improve the immunological status and promoted the growth. It improved the haemoglobin concentration 
though it reduced the Serum Protein and Cholesterol levels. There by the Bala Rogaghna, Balya, Brimhana, Medhya effect stands proved justifying the selection of the drug here for this study.

\section{ACKNOWLEDGEMENT}

This study was carried out with the Financial support and sponsorship from Advanced Research Department of Rajiv Gandhi University of Health Sciences, Karnataka, Bengaluru. The authors would like to thank for their support.

\section{RefERENCES}

1. Ghai Essentials of Pediatrics, $9^{\text {th }}$ edition, 2019. Dr Vinod K. Paul, Dr.Arvind Bagga, p346

2. Bruch H. Eating disorders: Obesity, anorexia nervosa, and the person within (Vol. 5052). Basic Books. $1973 ; 5052$

3. Nicholas A. Boon, Nicki R. Colledge, Brian R. Walker, John A.A. Hunter, editor, Davidson's Principles and Practice of Medicine. 20th ed., New York; Churchill Livingstone Elsevier: 2006, pg 117.

4. K.Park, Textbook of Preventive and social Medicine, $23^{\text {rd }}$ Edition, $\mathrm{M} / \mathrm{s}$ Banarasidas Bhanot, Jabalpur, p412,pp671

5. Morley JE, Silver AJ. Nutritional issues in nursing home care. Ann Inter Med.1995; 123(11):850-9.

6. Acarya Vagbhata, Ashtanga Hridaya, Arunadatta and Hemadri Sanskrit commentary, Chaukambha Surabharati Prakashan, Varanasi, 1997 .P784;pp956
7. Acarya Caraka, Caraka Samhita, edi Acarya Yadavji Trikamji, chaukambha prakashan, Varanasi, 2013, pg219;pp738

8. Acarya Caraka, Caraka Samhita, edi Acarya Yadavji Trikamji, chaukambha prakashan, Varanasi, 2013, pg 117

9. Acarya Sushruta, SushrutaSamhita, with Acarya Dalhana's Nibandha Sangraha Commentary, edited Acarya Yadavji Trikamji, Chaukambha Surabharati Prakashan, Varanasi, Reprint 1997.p64,pp714.

10. Acarya Vrddha Jeevaka, Kashyapa Samhita, Hindi Translation Bhishagacharya Sri Satyapal, Chaukambha Sanskrit Samsthan, Varanasi,prnt 1998,p139140.pp364.

11. Govinda Dasa, Bhaishajya Ratnavali, Hindi translation by Sidhinandan Mishra, Chaukambha surabharati prakashan, Varanasi, 2012, pg 1087

How to cite this article: Dr. Pradeep EK, Dr. Ravishankar Shenoy. Evaluation of the efficacy of Shiva modaka on Hematological, Biochemical and Immunological Parameters in the management of malnutrition among school going children. J Ayurveda Integr Med Sci 2020;1:6-9. http://dx.doi.org/10.21760/jaims.5.1.2

Source of Support: RGUHS Dept. of Advanced Research, Conflict of Interest: None declared.

Copyright (C 2020 The Author(s); Published by Maharshi Charaka Ayurveda Organization, Vijayapur (Regd). This is an open-access article distributed under the terms of the Creative Commons Attribution License (http://creativecommons.org/licenses/by/4.0), which permits unrestricted use, distribution, and reproduction in any medium, provided the original work is properly cited. 